\title{
PENANGANAN PRODUKSI BUAH PISANG PASCA PANEN MELALUI MODEL PENGENDALIAN GAS ETILEN
}

\author{
M. Dafri', R. Ratianingsih², Hajar ${ }^{3}$ \\ 1,2,3Program Studi Matematika Jurusan Matematika FMIPA Universitas Tadulako \\ Jalan Soekarno-Hatta Km. 09 Tondo, Palu 94118, Indonesia. \\ 1muh.dafri57@gmail.com, 2ratianingsih@yahoo.com, ${ }^{3}$ hajar.200490@yahoo.com
}

\begin{abstract}
Bananas is a kind of fruit that has many benefits and economic value. However, because it is perishable, an unappropriate post-harvest handling will decreasing the economic value. Many factors affect the ripening of bananas, one of it is ethylene gas. The ethylene gas that contained in the banana flows from the higher concentration to the lower one. The flow should be controlled in order to make it decaying properly. Temperature is a parameter that affects the flow of ethylene. This research offers storage temperature regulation such that the life time of banana could be extended. A mathematical model that represents the ethylene flow among the subpopulations is discussed. The population are devided into sub-population of unripe bananas, normal ripe bananas, ripe bananas wounds, and rotten bananas. The Stability of the model is evaluated in the critical point by Jacobian matrix and the Routh Hurwitz Criteria. The control is design by minimizing the temperature parameters using the Pontryagin Minimum Principle. Simulation is ilustrated in four cases, the firts case is no bananas wound initially, second case is no bananas rot initially, third case is no ripened normal bananas initially, and the fourth case is the bananas ripe initially exiting. The simulations shows that before controling the temperature, in the amount of 120 bananas of firts case, the proces is condcuted in sixteen days, ten days for the second case, nine days for the third case, and eight days for the fourth case. After controling the temperature, for some amount of bananas of firts case, the proces is conduted in seventeen days, eleven days for the second case, ten days for the third case, and nine days for the fourth case.
\end{abstract}

Keywords : Dynamic Model, Ethylene gas, Jacobian matrix, Optimal control, Pontryagin Minimum Principle, Routh Hurwitz criteria.

\section{ABSTRAK}

Buah pisang merupakan salah satu buah yang memiliki banyak manfaat dan juga memiliki nilai ekonomis. Namun, karena sifatnya yang mudah busuk, penangan buah pisang pasca panen yang tidak tepat menurunkan nilai ekonomis. Banyak faktor yang mempengaruhi pematangan buah pisang, salah satu faktor yang penting untuk ditinjau adalah gas etilen. Gas etilen yang terkandung pada buah pisang akan mengalir dari buah pisang ke buah pisang lain yang mengandung gas etilen lebih rendah. Aliran ini perlu dikendalikan agar tidak membuat buah pisang cepat busuk. Suhu merupakan parameter yang berpengaruh terhadap aliran gas etilen. Penelitian ini menawarkan pengaturan suhu pada tempat penyimpanan buah pisang sehingga aliran gas etilen dikendalikan untuk memperpanjang usia penyimpanan buah pisang. Dibangun model matematika yang merepresentasikan aliran gas etilen antar sub populasi dalam tempat penyimpanan buah pisang, yaitu sub populasi pisang mentah, 
pisang matang normal, pisang matang luka, dan pisang busuk. Model dinamik tersebut dianalisis kestabilan di titik kritisnya melalui Matriks Jacobi dan Kriteria Routh Hurwitz. Pengendalian gas etilen dilakukan dengan meminimumkan parameter S (suhu tempat penyimpanan) untuk tujuan memperpanjang masa simpan buah pisang. Solusi optimal ditentukan dengan menggunakan prinsip minimum pontryagin. Simulasi untuk kelompok sub populasi buah pisang diamati dalam empat kasus yaitu, kasus I tidak ada buah pisang matang luka dalam ruang penyimpanan, kasus II Tidak ada buah pisang busuk dalam ruang penyimpanan, kasus III Tidak ada buah pisang matang normal dalam ruang penyimpanan, dan kasus IV terdapat buah pisang matang normal dan buah pisang matang luka dalam ruang penyimpanan. Simulasi menunjukan bahwa sebelum dilakukan pengaturan suhu, buah pisang yang sebanyak 120 buah pada kasus I akan habis pada hari keenambelas, pada kasus II akan habis pada hari kesepuluh, pada kasus III akan habis pada hari kesembilan, dan pada kasus IV akan habis pada hari delapan. Setelah dilakukan pengaturan suhu, 120 buah pisang pada kasus I akan habis pada hari ketujuhbelas, pada kasus II akan habis pada hari kesebelas, pada kasus III akan habis pada hari kesepuluh, dan pada kasus IV akan habis pada hari kesembilan.

Kata Kunci : Model Dinamik, Gas Etilen, Matriks Jacobi, Kendali Optimal, Prinsip Minimum Pontryagin, Kriteria Routh Hurwitz.

\section{PENDAHULUAN}

\subsection{Latar Belakang}

Pisang merupakan tanaman yang banyak tumbuh di Indonesia yang dikenal sebagai salah satu negara produsen pisang dunia. Menurut Direktorat Jendral Tanaman Pangan dan Hortikulura produksi pisang di Indonesia pada tahun 2001 mencapai 4.300 .000 ton, sedangkan produksi pisang di Sumatera Barat pada 2008 sebanyak 7.138 .50 (Sari, 2011). Namun melimpahnya produksi pisang serta penanganan buah pisang pasca panen yang kurang baik membuat nilai ekonomis buah pisang menjadi rendah.

Buah pisang merupakan jenis buah klimakterik yaitu buah yang mengalami peningkatan laju respirasi yang tinggi selama proses pematangan. Jenis buah klimaterik adalah buah yang tetap melanjutkan proses pematangannya meskipun sudah dipetik (Setiono, 2011). Sebagai buah klimakterik, buah pisang menghasilkan lebih banyak etilen endogen daripada buah nonklimakterik. Gas etilen yang dihasilkan akan mempengaruhi pematangan buah pisang lain yang ada disekitarnya, bahkan buah pisang yang cacat/luka akan menghasilkan gas etilen yang lebih banyak dari pada buah pisang yang normal (Paramita, 2010). Selain keberadaan pisang yang luka, produksi etilen juga dipengaruhi oleh faktor suhu. Suhu rendah dapat menekan produksi gas etilen pada buah klimaterik, oleh karena itu suhu rendah banyak dipergunakan dalam pengaturan penyimanan buah buahan klimaterik (Utama, 2001). Namun demikian suhu yang terlalu rendah juga dapat membuat buah menjadi rusak.

Etilen merupakan hormon yang berbentuk gas dan berperan penting di dalam proses pematangan buah. Kandungan gas etilen yang terdapat pada buah-buahan klimakterik mengalami perubahan proses pematangan, misalnya pada pisang yang akan memasuki 
proses pematangan, kandungan etilen yang ada di dalamnya kira-kira $0-0.5 \mathrm{ppm}$ dan akan meningkat pada saat puncak klikmaterik dengan kandungan etilen kurang lebih 130 ppm (Hayati, 2012).

Seperti halnya buah-buahan klimakterik lainnya, proses pematangan buah pisang perlu diatur agar daya simpan buah dapat di perpanjang. Hal ini disebabkan proses pematangan yang cepat mempersulit penanganan pasca panen seperti penyortiran, penyimpanan, serta pendistribusian untuk diolah (Fenny, 2002). Dalam penelitian ini dibangun model matematika yang mempresentasikan interaksi antar sub populasi dalam tempat penyimpanan buah pisang. Model dinamik tersebut dianalisis kestabilannya melalui Matriks Jacobi dan Kriteria Routh Hurwitz di titik kritis. Pengendalian gas etilen dilakukan dengan mengontrol parameter S (suhu tempat penyimpanan) untuk tujuan memperpanjang masa simpan buah pisang. Solusi optimal ditentukan dengan menggunakan prinsip minimum pontryagin.

\subsection{Rumusan Masalah}

Bagaimana model matematika yang merepresentasikan interaksi antar sub populasi dalam tempat penyimpanan buah pisang pasca panen dan menganalisis kestabilan model serta bagaimana kendali optimal suhu penyimpanan yang meminimumkan gas etilen sehingga dapat memperpanjang masa penyimpanan buah pisang pasca panen.

\subsection{Tujuan}

Mendapatkan model matematika yang merepresentasikan interaksi antar sub populasi dalam tempat penyimpanan buah pisang pasca panen dan menganalisis kestabilan model serta bagaimana kendali optimal suhu penyimpanan yang meminimumkan gas etilen sehingga dapat memperpanjang masa penyimpanan buah pisang pasca panen.

\section{METODE PENELITIAN}

Metode penelitian ini menggunakan penelusuran literatur dengan menelaah artikel dan jurnal ilmiah terkait buah pisang pasca panen terutama mengenai pengaruh gas etilen terhadap proses pematangan buah pisang dengan tahapan sebagai berikut :

1. Membangun model interaksi gas etilen dalam proses pematangan buah pisang pasca panen.

2. Menganalisis kestabilan model matematika menggunakan matriks Jacobi dan Kriteria RouthHurwitz.

3. Memasukkan parameter $\mathrm{S}$ dalam model dan menyelesaikan masalah optimal model proses pematangan buah pisang melalui pengaturan suhu penyimpanan dengan metoda Minimum Pontryagin. 


\subsection{Model Matematika}

Model adalah suatu konsep atau objek yang digunakan untuk menggambar suatu kenyataan dan mendapatkan suatu bentuk yang dapat dipahami. Model merupakan simplifikasi atau penyederhanaan fenomena-fenomena nyata dalam bentuk matematika. Model matematika adalah sebuah model yang bagian-bagiannya merupakan konsep matematika, seperti konstanta, variabel, fungsi, persamaan, pertidaksamaan dan sebagainya (Mayer, 1985).

Pemodelan matematika merupakan salah satu tahap dari pemecahan masalah matematika. Pemodelan matematika bertujuan untuk mendiskripsikan fenomena alam ke dalam bentuk persamaan matematika. Ketetapan formulasi persamaan matematika sangat berpengaruh terhadap kecocokan dari fenomena tersebut agar tidak terjadi kesalahan interpretasi dalam membentuk persamaan matematika. (Luknanto, 2003).

Dalam penelitian ini aliran etilen dipandang sebagai penyebab perpindahan fase kematangan pada buah pisang. Aliran ini dalam model dinyatakan sebagai transfer etilen antar sub poplasi. Berdasarkan kandungan gas etilennya, populasi buah pisang dibagi dalam kelompok pisang mentah, pisang matang, dan pisang busuk. Selain itu, berdasarkan kecacatannya, buah pisang juga digolongkan dalam dua kelompok, yaitu buah pisang normal dan buah pisang yang luka. Sehingga populasi buah pisang yang dikelompokkan berdasarkan kandungan gas etilen dan kematanganya terdiri atas sub populasi pisang normal yang mentah $(P)$, sub populasi buah pisang yang normal matang $(P m)$, sub poulasi buah pisang luka yang matang $(P m)$, dan sub poplasi buah pisang busuk $(P b)$. Pada sub populasi $\mathrm{Pb}$, sebagian buah pisang busuk yang dipandang tidak dapat dikonsumsi lagi akan dikeluarkan dari tempat penyimpanan.

\subsection{Kriteria Kestabilan Routh-Hurwitz}

Kriteria kestabilan Routh-Hurwitz adalah suatu metode yang mengkaji kestabilan sistem dengan hanya memperhatikan koefisien dari persamaan karateristik tanpa menghitung akarakar karateristik secara langsung (Subiono,2013). Diberikan suatu persamaan karateristik dengan orde ke-n sebagai berikut :

$f(\lambda)=a_{0} \lambda^{n}+a_{1} \lambda^{n-1}+a_{2} \lambda^{n-2}+\cdots+a_{n-1} \lambda+a_{n}=0$

Sistem dikatakan stabil jika tidak ada perubahan tanda dalam kolom pertama pada tabel Kriteria Routh-Hurwitz yaitu semuanya bertanda positif atau negatif.

Tabel 1 : Kriteria Routh-Hurwitz

\begin{tabular}{|c|c|c|c|}
\hline$\lambda^{n}$ & $a_{n}$ & $a_{n-2}$ & $a_{n-4}$ \\
\hline$\lambda^{n-1}$ & $a_{n-1}$ & $a_{n-3}$ & $a_{n-5}$ \\
\hline$\lambda^{n-2}$ & $b_{1}$ & $b_{2}$ & $b_{3}$ \\
\hline
\end{tabular}




\begin{tabular}{|c|c|c|c|}
\hline$\lambda^{n-3}$ & $c_{1}$ & $c_{2}$ & $c_{3}$ \\
\hline$\lambda^{n-3}$ & $d_{1}$ & $d_{2}$ & $d_{3}$ \\
$\vdots$ & $\vdots$ & $\vdots$ & $\vdots$ \\
\hline$\lambda^{2}$ & $e_{1}$ & $e_{2}$ & \\
$\lambda$ & $f_{1}$ & & \\
\hline$\lambda^{0}$ & $g_{1}$ & & \\
\hline
\end{tabular}

Nilai $b_{1}, b_{2}, b_{3}, c_{1}, c_{2}$ dan $c_{3}$ pada tabel 1 diperoleh dari perhitungan berikut ini :

$$
\begin{array}{lll}
b_{1}=\frac{a_{n-1} a_{n-2}-a_{0} a_{n-3}}{a_{n-1}} & b_{2}=\frac{a_{n-1} a_{n-4}-a_{n} a_{n-5}}{a_{n-1}} & b_{n}=\frac{a_{1} a_{2 n}-a_{0} a_{2 n+1}}{a_{1}} \\
c_{1}=\frac{b_{1} a_{n-3}-a_{n-1} b_{2}}{b_{1}} & c_{2}=\frac{b_{1} a_{n-5}-a_{n-1} b_{3}}{b_{1}} & c_{n}=\frac{b_{1} a_{2 n+1}-a_{1} b_{n+1}}{b_{1}}
\end{array}
$$

\subsection{Prinsip Minimum Pontryagin}

Penyelesaian masalah kendali optimal dengan menggunakan metode tidak langsung dilakukan dengan menyelesaikan kondisi perlu kendali optimal. Berdasarkan prinsip maksimum pontryagin, kondisi perlu dari masalah dari kendali optimal yang harus diselesaikan adalah persamaan stasioner, persamaan state, dan persamaan costate serta kondisi transversality.

Langkah penyelesaian masalah kendali optimal adalah sebagai berikut (Naidu, 2002).

a. Bentuk fungsi Hamilton

$$
H(x(t), u(t), \lambda(t), t)=L(x(t), u(t), t)+\lambda^{\prime} f(x(t), u(t), t)
$$

b. Meminimumkan $H$ terhadap $u(t)$

$$
\frac{\partial H}{\partial u}=0
$$

Sehingga diperoleh kondisi stasioer

$$
u^{*}(t)=\left(x^{*}(t), \lambda^{*}(t), t\right)
$$

c. Selanjutnya akan diperoleh fungsi Hamilton baru yang optimal $\left(u^{*}\right)$, dengan persamaan

$$
H^{*}\left(x^{*}(t), u^{*}(t), \lambda^{*}(t), t\right)=H\left(x^{*}(t), u^{*}(t), \lambda^{*}(t), t\right)
$$

d. Menyelesaikan persamaan state dan costate

$$
\dot{x}(t)=\frac{\partial H^{*}}{\partial \lambda} \operatorname{dan} \dot{\lambda}(t)=\frac{\partial H^{*}}{\partial x}
$$

Dengan kondisi batas diberikan oleh keadaan awal dan keadan akhir yang disebut kondisi transversality

e. Substitusi hasil yang diperoleh pada langkah 4 kedalam persamaan $u^{*}(t)$ pada langka 2 untuk mendapatkan kendali optimal.

Kondisi batas transversality dibedakan menjadi lima tipe berdasarka perbedaan antara $t_{f}$ dan state pada waktu akhir $\left(x\left(t_{f}\right)\right)$ yaitu:

a. Waktu akhir dan state saat waktu akhir telah ditentukan atau diketahui.

$$
x\left(t_{o}\right)=x_{0} ; x\left(t_{f}\right)=x_{f}
$$

b. Waktu akhir belum ditentukan atau tidak diketahui dan state saat waktu akhir telah ditentukan atau diketahui

$$
x\left(t_{o}\right)=x_{0} ; x\left(t_{f}\right)=x_{f},\left(H^{*}+\frac{\partial S}{\partial t}\right)_{t f}=0
$$


c. Waktu akhir telah ditentukan atau diketahui sedangkan state saat waktu akhir belum diketahui atau tidak ditentukan

$$
x\left(t_{0}\right)=x_{0}, \lambda^{*}\left(t_{f}\right)=\left(\frac{\partial S}{\partial x}\right)_{* t f}
$$

d. Waktu akhir belum ditentukan atau tidak diketahui dan state saat akhir belum ditentukan atau tidak diketahui dan nilainya bergantung pada sesuatu

$$
\begin{gathered}
x\left(t_{o}\right)=x_{0} ; x\left(t_{f}\right)=\varphi\left(t_{f}\right) \\
\left(H^{*}+\frac{\partial S}{\partial t}+\left(\left(\frac{\partial S}{\partial x}\right)_{*}-\lambda^{*}(t)\right)^{\prime} \varphi(t)\right)_{t f}=0
\end{gathered}
$$

e. Waktu akhir belum ditentukan atau tidak diketahui dan state saat akhir belum ditentukan atau tidak diketahui dan nilainya tidak bergantung pada sesuatu.

$$
\begin{gathered}
\gamma x\left(t_{0}\right)=x_{0} \\
\left(H^{*}+\frac{\partial S}{\partial t}\right)_{t f}=0,\left(\left(\frac{\partial S}{\partial t}\right)_{*}-\lambda^{*}(t)\right)_{t f}=0
\end{gathered}
$$

\section{HASIL DAN PEMBAHASAN}

Proses pematangan buah pisang, yang di indikasi dari kandungan gas etilen dari buah pisang, dikaji melalui model matematika yang dibangun berdasarkan fenomena terjadinya aliran gas etilen dari buah pisang yang kadungan gas etilennya lebih tinggi ke pisang dengan kandungan gas etilen lebih rendah. sehingga diperoleh sistem persamaan diferensial yang mempresentasikan perkembangan dari setiap tahap proses pematangan buah pisang

\subsection{Kontruksi Model Matematika}

Berdasarkan kandungan gas etilennya, populasi buah pisang dibagi dalam kelompok pisang mentah, pisang matang, dan pisang busuk. Selain itu, berdasarkan kecacatannya, buah pisang juga digolongkan dalam dua kelompok, yaitu buah pisang normal dan buah pisang yang luka. Sehingga populasi buah pisang yang dikelompokkan berdasarkan kandungan gas etilen dan kematanganya terdiri atas sub populasi pisang normal yang mentah $(P)$, sub populasi buah pisang yang normal matang ( $\mathrm{Pm})$, sub poulasi buah pisang luka yang matang (Pml), dan sub poplasi buah pisang busuk $(\mathrm{Pb})$. Pada sub populasi $\mathrm{Pb}$, sebagian buah pisang busuk yang dipandang tidak dapat dikonsumsi lagi akan dikeluarkan dari tempat penyimpanan. Dalam penelitian ini aliran etilen dipandang sebagai penyebab perpindahan fase kematangan pada buah pisang. Aliran ini dalam model dinyatakan sebagai transfer etilen antar sub poplasi. Aliran perpindahan kelompok sub populasi dinyatakan pada Gambar 1. 


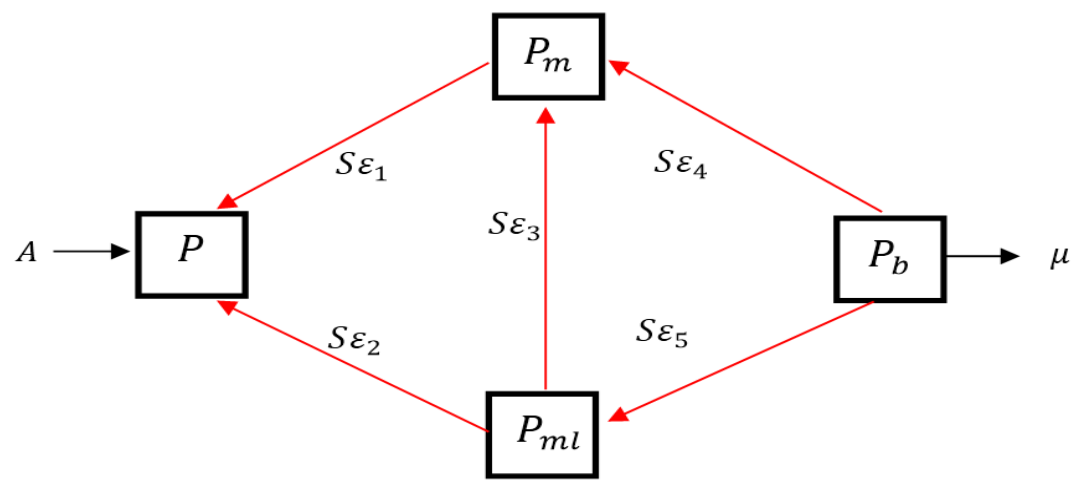

Gambar 1 : Diagram Kompartemen Transfer Gas Etilen Dalam Proses Pematangan Buah Pisang

Dari diagram pada Gambar 1 dibangun model matematika yang dinyatakan dalam sistem persamaan diferensial (SPD) sebagai berikut :

$\frac{d P}{d t}=A-\frac{S \varepsilon_{1} P m P}{N}-\frac{S \varepsilon_{2} P m l P}{N}$

$\frac{d P m}{d t}=\frac{S \varepsilon_{1} P m P}{N}-\frac{S \varepsilon_{3} P m l P m}{N}-\frac{S \varepsilon_{4} P b P m}{N}$

$\frac{d P m l}{d t}=\frac{S \varepsilon_{2} P m l P}{N}-\frac{S \varepsilon_{5} P m l P b}{N}$

$\frac{d P b}{d t}=\frac{S \varepsilon_{3} P m l P m}{N}+\frac{S \varepsilon_{4} P b P m}{N}+\frac{S \varepsilon_{5} P m l P b}{N}-\mu P b$

Keterangan :

$P \quad$ : Populasi buah pisang mentah

$P_{m} \quad$ : Populasi buah pisang matang

$P_{m l} \quad$ : Populasi buah pisang matang yang luka

$P_{b} \quad$ : Populasi buah pisang busuk

$A \quad$ : Tingkat buah pisang mentah yang masuk ke penyimpanan

$\mu \quad$ : Tingkat buah pisang busuk yang keluar dari penyimpanan

$\varepsilon_{1} \quad$ : Tingkat transfer etilen $P_{m}$ ke $P$

$\varepsilon_{2} \quad$ : Tingkat transfer etilen $P_{m /}$ ke $P$

$\varepsilon_{3} \quad:$ Tingkat transfer etilen $P_{m /}$ ke $P_{m}$

$\varepsilon_{4} \quad$ : Tingkat transfer etilen $P_{b}$ ke $P_{m}$

$\varepsilon_{5} \quad$ : Tingkat transfer etilen $P_{b}$ ke $P_{m l}$

$S \quad$ : Suhu ruang penyimpanan

$N \quad$ : Jumlah populasi buah pisang 
Titik kritis model yang dibangun diperoleh dengan meninjau SPD pada keadaan stagnan, sehingga diperoleh tiga titik kritis tak nol sebagai berikut :

$$
\begin{aligned}
& T_{1}=\left(\frac{\varepsilon_{4} A}{\mu \varepsilon_{1}}, \frac{\mu N}{S \varepsilon_{4}}, 0, \frac{A}{\mu}\right), T_{2}=\left(\frac{\varepsilon_{5} A}{\mu \varepsilon_{2}}, 0, \frac{\mu N}{S \varepsilon_{5}}, \frac{A}{\mu}\right), \\
& T_{3}=\left(\frac{\varepsilon_{5} A}{\mu \varepsilon_{2}}, \frac{\mu^{2} \varepsilon_{2} N \varepsilon_{3}-S A \varepsilon_{1} \varepsilon_{5}^{2}+S \varepsilon_{5} A \varepsilon_{4} \varepsilon_{2}}{S \varepsilon_{3} \varepsilon_{1} \varepsilon_{5} \mu}, \frac{A\left(\varepsilon_{1} \varepsilon_{5}-\varepsilon_{2} \varepsilon_{4}\right)}{\varepsilon_{3} \varepsilon_{2} \mu}, \frac{A}{\mu}\right)
\end{aligned}
$$

Model pada persamaan (1) - (4) memiliki titik kritis yang menggambarkan banyaknya populasi pada tiap fase dari proses pematangan buah pisang dalam kondisi stagnan. Kestabilan dari titik kritis tersebut ditentukan berdasarkan nilai eigen dan memperhatikan koefisien-koefisien dari persamaan karakteristik untuk mengidentifikasi akar - akar karateristik yang dievaluasi di titik kritis $\left(P^{*}, P_{m}{ }^{*}, P_{m l}{ }^{*}, P_{b}{ }^{*}\right)$. Titik kritis dianalisis kestabilanya dengan metoda Routh Hurwitz. Analisis kestabilan memperlihatkan bahwa $T_{1}$ dan $T_{2}$ adalah titik kritis stabil, dan $T_{3}$ adalah titik kritis tidak stabil.

\subsection{Desain Kendali}

Kandungan gas etilen pada buah pisang dapat dipengaruhi oleh suhu. Peningkatan suhu pada tempat penyimpanan dapat mengakibatkan peningkatan produksi gas etilen oleh buah pisang. Suhu tempat penyimpanan yang terlalu rendah juga dapat membuat kualitas buah pisang menjadi rusak. Oleh kerena itu dalam penelitian ini gas etilen akan dikontrol melalui pengaturan suhu. Secara matematis pengaturan suhu dilakukan dengan menempatkan parameter S di setiap suku pada SPD yang memuat parameter etilen. Untuk memperpanjang masa simpan buah pisang perlu diminimukan kandungan gas etilen pada buah pisang, sehingga untuk menentukan nilai parameter $\mathbf{S}$ optimal yang meminimumkan kandungan gas etilen digunakan metode kendali optimal.

Masalah kendali optimal SPD diperoleh dengan membangun suatu performance index kontrol gas etilen dengan pengaturan suhu, yaitu :

$$
J[S]=\int_{0}^{t f} P b(t)+P m(t)+P m l(t)+S(t)^{2} d t
$$

Perfomance index dibangun untuk meminimumkan banyaknya buah pisang yang busuk, menahan pematangan buah pisang dalam interval yang lebih panjang serta menekan suhu pada kondisi minimal.Untuk meminimumkannya, metode Minimum Pontryagin menyatakan perlunya penentuan fungsi Hamiltonian, sebagai berikut :

$H=f(x, S, t)+\lambda g(x, S, t)$

$H=\left[P b+P m+P m l+S^{2}\right]+\lambda_{1}\left[A-\frac{S \varepsilon_{1} P m P}{N}-\frac{S \varepsilon_{2} P m l P}{N}\right]$ 


$$
\begin{aligned}
& +\lambda_{2}\left[\frac{S \varepsilon_{1} P m P}{N}-\frac{S \varepsilon_{3} P m l P m}{N}-\frac{S \varepsilon_{4} P b P m}{N}\right]+\lambda_{3}\left[\frac{S \varepsilon_{2} P m l P}{N}-\frac{S \varepsilon_{5} P m l P b}{N}\right] \\
& +\lambda_{4}\left[\frac{S \varepsilon_{3} P m l P m}{N}+\frac{S \varepsilon_{4} P b P m}{N}+\frac{S \varepsilon_{5} P m l P b}{N}-\mu P b\right]
\end{aligned}
$$

Penyelesaian masalah kendali optimal dengan parameter $\mathrm{S}$ sebagai pengontrol diperoleh melalui persamaan state, co-state, dan kondisi stasioner sebagai berikut :

a. Persamaan State

Persamaan state diturunkan dari persamaan (5), sebagai berikut :

$\frac{\partial H}{\partial \lambda_{1}}=A-\frac{S \varepsilon_{1} P m P}{N}-\frac{S \varepsilon_{2} P m l P}{N}$

$\frac{\partial H}{\partial \lambda_{2}}=\frac{S \varepsilon_{1} P m P}{N}-\frac{S \varepsilon_{3} P m l P m}{N}-\frac{S \varepsilon_{4} P b P m}{N}$

$\frac{\partial H}{\partial \lambda_{3}}=\frac{S \varepsilon_{2} P m l P}{N}-\frac{S \varepsilon_{5} P m l P b}{N}$

$\frac{\partial H}{\partial \lambda_{4}}=\frac{S \varepsilon_{3} P m l P m}{N}+\frac{S \varepsilon_{4} P b P m}{N}+\frac{S \varepsilon_{5} P m l P b}{N}-\mu P b$

b. Persamaan Co-State

Persamaan co-state diturunkan dari persamaan (5), sebagai berikut :

$$
\begin{aligned}
& \frac{\partial H}{\partial P}=\lambda_{1}\left[-\frac{S \varepsilon_{1} P m}{N}-\frac{S \varepsilon_{2} P m l}{N}\right]+\lambda_{2}\left[\frac{S \varepsilon_{1} P m}{N}\right]+\lambda_{3}\left[\frac{S \varepsilon_{2} P m l}{N}\right] \\
& \frac{\partial H}{\partial P m}=1+\lambda_{1}\left[-\frac{S \varepsilon_{1} P}{N}\right]+\lambda_{2}\left[\frac{S \varepsilon_{1} P}{N}-\frac{S \varepsilon_{3} P m l}{N}-\frac{S \varepsilon_{4} P b}{N}+\right]+\lambda_{4}\left[\frac{S \varepsilon_{3} P m l}{N}+\frac{S \varepsilon_{4} P b}{N}\right] \\
& \frac{\partial H}{\partial P m l}=1+\lambda_{1}\left[-\frac{S \varepsilon_{2} P}{N}\right]+\lambda_{2}\left[-\frac{S \varepsilon_{3} P m}{N}\right]+\lambda_{3}\left[\frac{S \varepsilon_{2} P}{N}-\frac{S \varepsilon_{5} P b}{N}\right]+\lambda_{4}\left[\frac{S \varepsilon_{3} P m}{N}+\frac{S \varepsilon_{5} P b}{N}\right] \\
& \frac{\partial H}{\partial P b}=1+\lambda_{2}\left[-\frac{S \varepsilon_{4} P m}{N}\right]+\lambda_{3}\left[-\frac{S \varepsilon_{5} P m l}{N}\right]+\lambda_{4}\left[\frac{S \varepsilon_{4} P m}{N}+\frac{S \varepsilon_{5} P m l}{N}-\mu\right]
\end{aligned}
$$

c. Kondisi Stasioner

Persamaan kondisi stasioner diturunkan dari persamaan (5), sebagai berikut :

$$
\begin{aligned}
& \frac{\partial H}{\partial S}=0 \\
& 2 S+\lambda_{1}\left[-\frac{\varepsilon_{1} P m P}{N}-\frac{\varepsilon_{2} P m l P}{N}\right]+\lambda_{2}\left[\frac{\varepsilon_{1} P m P}{N}-\frac{\varepsilon_{3} P m l P m}{N}-\frac{\varepsilon_{4} P b P m}{N}\right] \\
& +\lambda_{3}\left[\frac{\varepsilon_{2} P m l P}{N}-\frac{\varepsilon_{5} P m l P b}{N}\right]+\lambda_{4}\left[\frac{\varepsilon_{3} P m l P m}{N}+\frac{\varepsilon_{4} P b P m}{N}+\frac{\varepsilon_{5} P m l P b}{N}\right]=0 \\
& -\lambda_{1}\left[-\varepsilon_{1} P m P-\varepsilon_{2} P m l P\right]-\lambda_{2}\left[\varepsilon_{1} P m P-\varepsilon_{3} P m l P m-\varepsilon_{4} P b P m\right] \\
& S^{*}=\frac{-\lambda_{3}\left[\varepsilon_{2} P m l P-\varepsilon_{5} P m l P b\right]-\lambda_{4}\left[\varepsilon_{3} P m l P m+\varepsilon_{4} P b P m+\varepsilon_{5} P m l P b\right]}{2 N}
\end{aligned}
$$

Batasan suhu yang diambil dalam penyimpanan buah pisang adalah $11^{\circ} \mathrm{C}-20^{\circ} \mathrm{C}$, sehingga. 


$$
S^{*}(t)=\left\{\begin{array}{cr}
11, & S(t) \geq 11 \\
S^{*}(t), & 0<S(t)<20 \\
20, & S(t) \leq 20
\end{array}\right.
$$

Kendali optimal $S^{*}(t)$ sebagai berikut :

$$
S^{*}(t)=\min \left\{20, m a k s\left(\left(\begin{array}{c}
-\lambda_{1}\left[-\varepsilon_{1} P m P-\varepsilon_{2} P m l P\right]-\lambda_{2}\left[\varepsilon_{1} P m P-\varepsilon_{3} P m l P m-\varepsilon_{4} P b P m\right] \\
\frac{-\lambda_{3}\left[\varepsilon_{2} P m l P-\varepsilon_{5} P m l P b\right]-\lambda_{4}\left[\varepsilon_{3} P m l P m+\varepsilon_{4} P b P m \mp \varepsilon_{5} P m l P b\right]}{2 N}
\end{array}\right), 11\right)\right\}
$$

Sehingga persamaan sistem dinamik terkontrol sebagai berikut :

$$
\begin{aligned}
& \frac{d P}{d t}=A-\frac{\left(\begin{array}{c}
-\lambda_{1}\left[-\varepsilon_{1} P m P-\varepsilon_{2} P m l P\right]-\lambda_{2}\left[\varepsilon_{1} P m P-\varepsilon_{3} P m l P m-\varepsilon_{4} P b P m\right] \\
-\lambda_{3}\left[\varepsilon_{2} P m l P-\varepsilon_{5} P m l P b\right]-\lambda_{4}\left[\varepsilon_{3} P m l P m+\varepsilon_{4} P b P m+\varepsilon_{5} P m l P b\right]
\end{array}\right) \varepsilon_{1} P m P}{2 N^{2}} \\
& -\frac{\left(\begin{array}{c}
-\lambda_{1}\left[-\varepsilon_{1} P m P-\varepsilon_{2} P m l P\right]-\lambda_{2}\left[\varepsilon_{1} P m P-\varepsilon_{3} P m l P m-\varepsilon_{4} P b P m\right] \\
-\lambda_{3}\left[\varepsilon_{2} P m l P-\varepsilon_{5} P m l P b\right]-\lambda_{4}\left[\varepsilon_{3} P m l P m+\varepsilon_{4} P b P m+\varepsilon_{5} P m l P b\right]
\end{array}\right) \varepsilon_{2} P m l P}{2 N^{2}} \\
& \frac{d P m}{d t}=\frac{\left(\begin{array}{c}
-\lambda_{1}\left[-\varepsilon_{1} P m P-\varepsilon_{2} P m l P\right]-\lambda_{2}\left[\varepsilon_{1} P m P-\varepsilon_{3} P m l P m-\varepsilon_{4} P b P m\right] \\
-\lambda_{3}\left[\varepsilon_{2} P m l P-\varepsilon_{5} P m l P b\right]-\lambda_{4}\left[\varepsilon_{3} P m l P m+\varepsilon_{4} P b P m+\varepsilon_{5} P m l P b\right]
\end{array}\right) \varepsilon_{1} P m P}{2 N^{2}} \\
& -\frac{\left(\begin{array}{c}
-\lambda_{1}\left[-\varepsilon_{1} P m P-\varepsilon_{2} P m l P\right]-\lambda_{2}\left[\varepsilon_{1} P m P-\varepsilon_{3} P m l P m-\varepsilon_{4} P b P m\right] \\
-\lambda_{3}\left[\varepsilon_{2} P m l P-\varepsilon_{5} P m l P b\right]-\lambda_{4}\left[\varepsilon_{3} P m l P m+\varepsilon_{4} P b P m+\varepsilon_{5} P m l P b\right]
\end{array}\right) \varepsilon_{3} P m l P m}{2 N^{2}} \\
& -\frac{\left(\begin{array}{c}
-\lambda_{1}\left[-\varepsilon_{1} P m P-\varepsilon_{2} P m l P\right]-\lambda_{2}\left[\varepsilon_{1} P m P-\varepsilon_{3} P m l P m-\varepsilon_{4} P b P m\right] \\
-\lambda_{3}\left[\varepsilon_{2} P m l P-\varepsilon_{5} P m l P b\right]-\lambda_{4}\left[\varepsilon_{3} P m l P m+\varepsilon_{4} P b P m+\varepsilon_{5} P m l P b\right]
\end{array}\right) \varepsilon_{4} P b P m}{2 N^{2}}
\end{aligned}
$$

$$
\begin{aligned}
\frac{d P m l}{d t}= & \frac{\left(\begin{array}{c}
-\lambda_{1}\left[-\varepsilon_{1} P m P-\varepsilon_{2} P m l P\right]-\lambda_{2}\left[\varepsilon_{1} P m P-\varepsilon_{3} P m l P m-\varepsilon_{4} P b P m\right] \\
-\lambda_{3}\left[\varepsilon_{2} P m l P-\varepsilon_{5} P m l P b\right]-\lambda_{4}\left[\varepsilon_{3} P m l P m+\varepsilon_{4} P b P m+\varepsilon_{5} P m l P b\right]
\end{array}\right) \varepsilon_{2} P m l P}{2 N^{2}} \\
& -\frac{\left(\begin{array}{c}
-\lambda_{1}\left[-\varepsilon_{1} P m P-\varepsilon_{2} P m l P\right]-\lambda_{2}\left[\varepsilon_{1} P m P-\varepsilon_{3} P m l P m-\varepsilon_{4} P b P m\right] \\
-\lambda_{3}\left[\varepsilon_{2} P m l P-\varepsilon_{5} P m l P b\right]-\lambda_{4}\left[\varepsilon_{3} P m l P m+\varepsilon_{4} P b P m+\varepsilon_{5} P m l P b\right]
\end{array}\right) \varepsilon_{5} P m l P b}{2 N^{2}}
\end{aligned}
$$

$$
\begin{aligned}
\frac{d P b}{d t}= & \frac{\left(\begin{array}{c}
-\lambda_{1}\left[-\varepsilon_{1} P m P-\varepsilon_{2} P m l P\right]-\lambda_{2}\left[\varepsilon_{1} P m P-\varepsilon_{3} P m l P m-\varepsilon_{4} P b P m\right] \\
-\lambda_{3}\left[\varepsilon_{2} P m l P-\varepsilon_{5} P m l P b\right]-\lambda_{4}\left[\varepsilon_{3} P m l P m+\varepsilon_{4} P b P m+\varepsilon_{5} P m l P b\right]
\end{array}\right) \varepsilon_{3} P m l P m}{2 N^{2}} \\
& +\frac{\left(\begin{array}{c}
-\lambda_{1}\left[-\varepsilon_{1} P m P-\varepsilon_{2} P m l P\right]-\lambda_{2}\left[\varepsilon_{1} P m P-\varepsilon_{3} P m l P m-\varepsilon_{4} P b P m\right] \\
-\lambda_{3}\left[\varepsilon_{2} P m l P-\varepsilon_{5} P m l P b\right]-\lambda_{4}\left[\varepsilon_{3} P m l P m+\varepsilon_{4} P b P m+\varepsilon_{5} P m l P b\right]
\end{array}\right) \varepsilon_{4} P b P m}{2 N^{2}} \\
& +\frac{\left(\begin{array}{c}
-\lambda_{1}\left[-\varepsilon_{1} P m P-\varepsilon_{2} P m l P\right]-\lambda_{2}\left[\varepsilon_{1} P m P-\varepsilon_{3} P m l P m-\varepsilon_{4} P b P m\right] \\
-\lambda_{3}\left[\varepsilon_{2} P m l P-\varepsilon_{5} P m l P b\right]-\lambda_{4}\left[\varepsilon_{3} P m l P m+\varepsilon_{4} P b P m+\varepsilon_{5} P m l P b\right]
\end{array}\right) \varepsilon_{5} P m l P b}{2 N^{2}}-\mu P b
\end{aligned}
$$

\subsection{Simulasi}

Simulasi dilakukan untuk merepresentasikan proses pengendalian gas etilen pada pematangan buah pisang yang ditampilkan pada Gambar 1. Pada bagian ini akan ditampilkan kurva yang menggambarkan banyaknya buah pisang masing-masing sub populasi pada setiap fase. Nilai-nilai parameter yang digunakan dalam simulasi dinyatakan dalam Tabel 2. 
Tabel 2 : Daftar nilai parameter

\begin{tabular}{|c|c|l|}
\hline Parameter & Nilai & Sumber \\
\hline$A$ & 0 & Asumsi \\
\hline$\mu$ & 1 & Asumsi \\
\hline$\varepsilon_{1}$ & 0.1625 & Asumsi \\
\hline$\varepsilon_{2}$ & 0.2167 & Asumsi \\
\hline$\varepsilon_{3}$ & 0.2167 & Asumsi \\
\hline$\varepsilon_{4}$ & 0.4333 & Asumsi \\
\hline$\varepsilon_{5}$ & 0.4333 & Asumsi \\
\hline
\end{tabular}

Sumber: Nurul H, 2012

Simulasi dilakukan untuk dua kondisi yaitu tanpa kendali suhu optimal dan dengan kendali suhu optimal. Simulasi tanpa kendali suhu dilakukan dengan menjaga suhu ruang penyimpanan dalam keadaan normal yaitu $20^{\circ} \mathrm{C}$ dan simulasi dengan kontrol suhu optimum dilakukan dengan menetapkan suhu ruang penyimpanan yang optimal dalam interval $11^{\circ} \mathrm{C}$ $20^{\circ} \mathrm{C}$. Simulasi digambarkan untuk empat keadaan, sebagai berikut :

Kasus I: Tidak ada buah pisang matang luka dalam ruang penyimpanan, yang disimulaskan untuk kondisi awal $P(0)=50, \operatorname{Pm}(0)=50, \operatorname{Pml}(0)=0$, dan $P b(0)=20$ dengan suhu $20^{\circ} \mathrm{C}$

Kasus II : Tidak ada buah pisang busuk dalam ruang penyimpanan, yang disimulasikan untuk kondisi awal $P(0)=50, P m(0)=50, P m l(0)=20$, dan $P b(0)=0$ dengan suhu $20^{\circ}$ C

Kasus III : Tidak ada buah pisang matang dalam ruang penyimpanan, yang disimulasikan untuk kondisi awal $P(0)=50, P m(0)=0, P m l(0)=50$, dan $P b(0)=20$ dengan suhu $20^{\circ}$ $\mathrm{C}$

Kasus IV : Terdapat buah pisang matang dan buah pisang matang luka dalam ruang penyimpanan, yang disimulasikan untuk kondisi awal $P(0)=30, \operatorname{Pm}(0)=30$, $\operatorname{Pml}(0)=30$, dan $P b(0)=30$ dengan suhu $20^{\circ} \mathrm{C}$

Dengan menggunakan software MATLAB diilustrasikan kurva kendali selama proses pematangan buah pisang dengan suhu di jaga pada suhu optimal $11^{\circ} \mathrm{C}$ digambarkan terhadap waktu. Gambar yang dapat dilihat pada Gambar 2. 


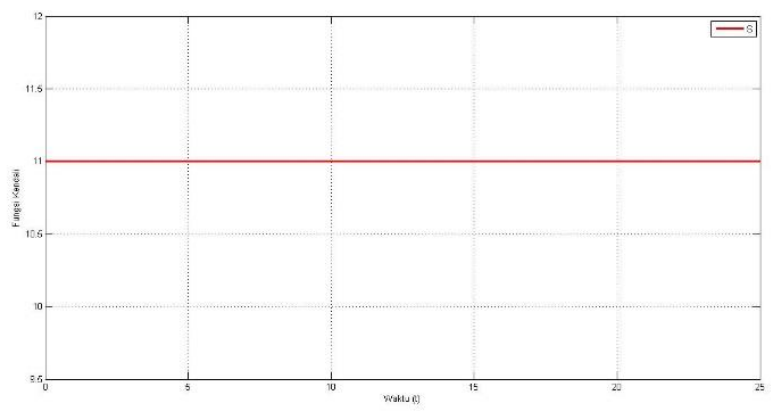

Gambar 2: Kurva Kendali Suhu Optimal

Selanjutnya dengan menggunakan Software MATLAB simulasi kasus I, kasus II, kasus III, dan kasus IV ditampilkan dalam gambar kurva berikut :

a. Kasus I
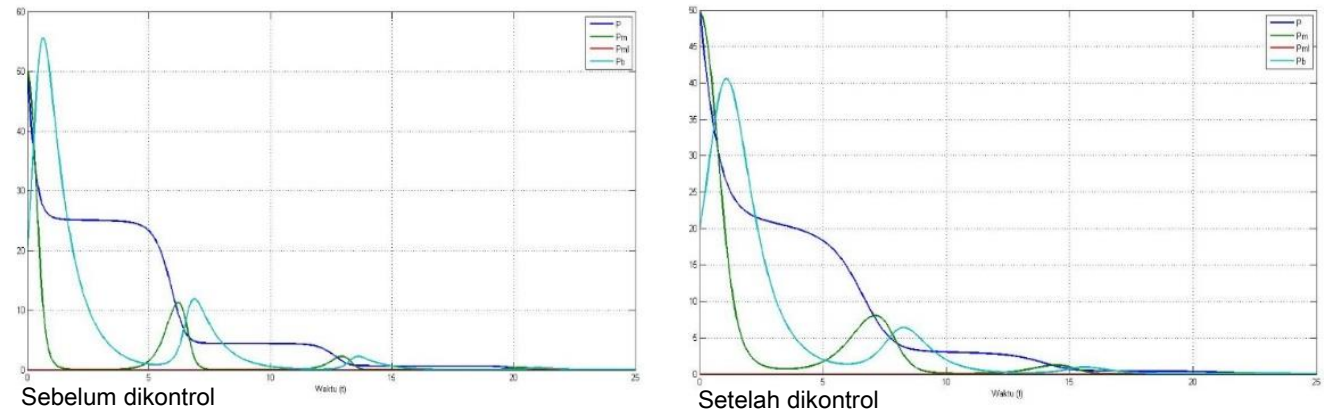

Gambar 3: Kurva kasus I sebelum dikontrol dan setelah dikontrol

Pada kasus I sebelum dikontrol, buah pisang habis pada hari keenambelas dan puncak tertinggi kurva pisang busuk $(P b)$ adalah 55. Setelah dikontrol dengan suhu optimum, buah pisang habis pada hari ketujuhbelas dan puncak tertinggi kurva pisang busuk $(P b)$ adalah 40 . Hal ini memperlihatkan waktu pematangan setelah dikontrol lebih lama dari pada sebelum dikontrol dan juga puncak tertinggi kurva pisang busuk $(P b)$ setelah dikontrol lebih rendah dari pada sebelum dikontrol. 
b. Kasus II

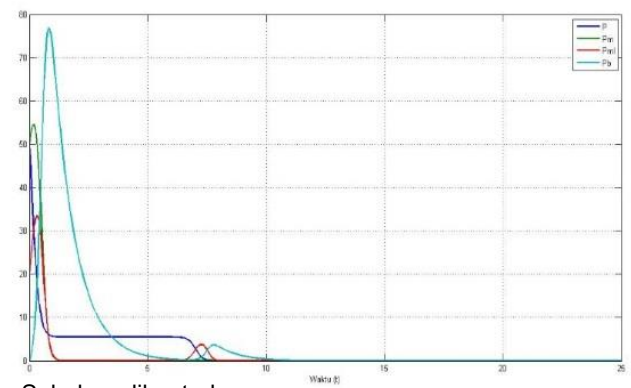

Sebelum dikontrol

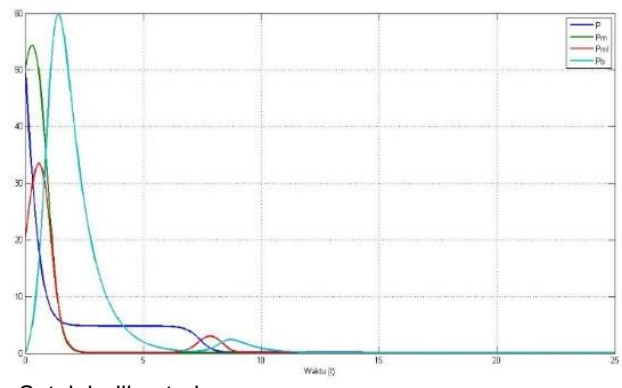

Setelah dikontrol

Gambar 4 : Kurva kasus II sebelum dikontrol dan setelah dikontrol

Pada kasus II sebelum dikontrol, buah pisang habis pada hari kesepuluh dan puncak tertinggi kurva pisang busuk $(P b)$ adalah 76 . Setelah dikontrol dengan suhu optimum, buah pisang habis pada hari kesebelas dan puncak tertinggi kurva pisang busuk $(P b)$ adalah 60 . Hal ini memperlihatkan waktu pematangan setelah dikontrol lebih lama dari pada sebelum dikontrol dan juga puncak tertinggi kurva pisang busuk $(P b)$ setelah dikontrol lebih rendah dari pada sebelum dikontrol.

c. Kasus III

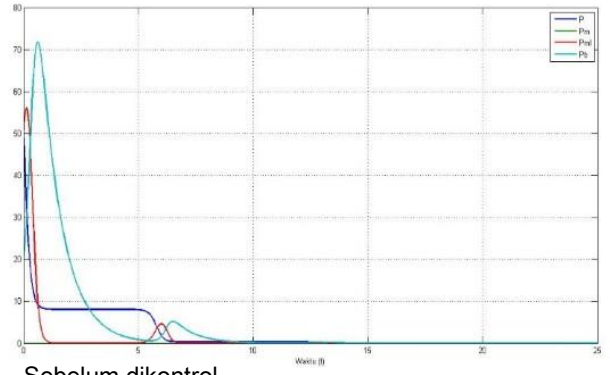

Sebelum dikontrol

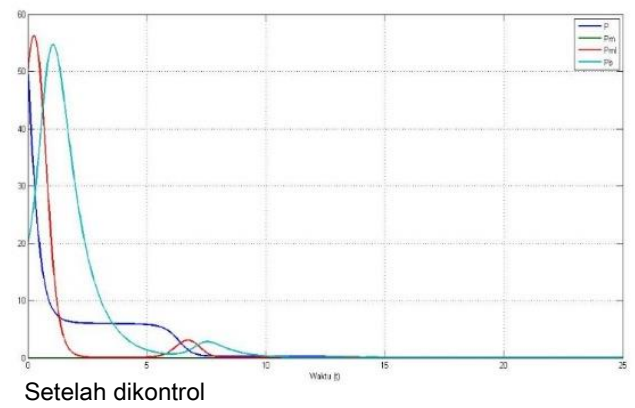

Setelah dikontrol

Gambar 5: Kurva kasus III sebelum dikontrol dan setelah dikontrol

Pada kasus III sebelum dikontrol, buah pisang habis pada hari kesembilan dan puncak tertinggi kurva pisang busuk $(P b)$ adalah 71 . Setelah dikontrol dengan suhu optimum, buah pisang habis pada hari kesepuluh dan puncak tertinggi kurva pisang busuk $(P b)$ adalah 55 . Hal ini memperlihatkan waktu pematangan setelah dikontrol lebih lama dari pada sebelum dikontrol dan juga puncak tertinggi kurva pisang busuk $(P b)$ setelah dikontrol lebih rendah dari pada sebelum dikontrol. 


\section{d. Kasus IV}

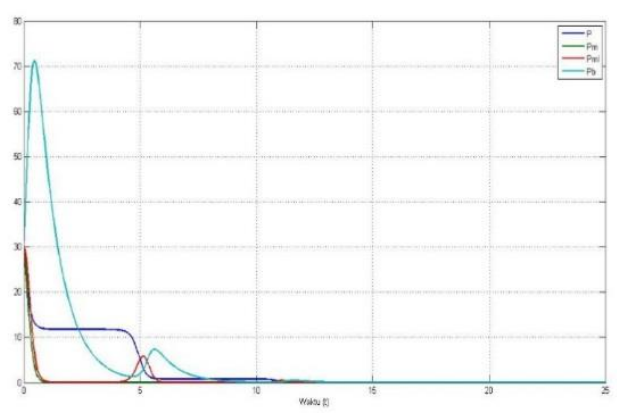

Sebelum dikontrol

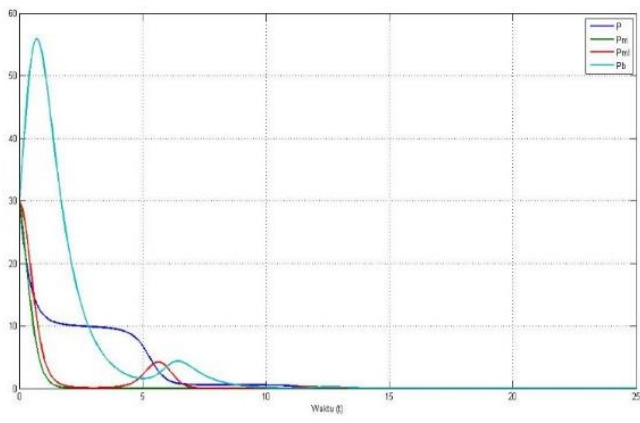

Setelah dikontrol

Gambar 6: Kurva kasus IV sebelum dikontrol dan setelah dikontrol

Pada kasus IV sebelum dikontrol, buah pisang habis pada hari kedelapan dan puncak tertinggi kurva pisang busuk $(P b)$ adalah 70 . Setelah dikontrol dengan suhu optimum, buah pisang habis pada hari kesembilan dan puncak tertinggi kurva pisang busuk $(P b)$ adalah 55. Hal ini memperlihatkan waktu pematangan setelah dikontrol lebih lama dari pada sebelum dikontrol dan juga puncak tertinggi kurva pisang busuk $(P b)$ setelah dikontrol lebih rendah dari pada sebelum dikontrol.

\section{KESIMPULAN}

Model pengendalian gas etilen bertujuan untuk memperpanjang masa simpan buah pisang pasca panen yang diperoleh, adalah sebagai berikut.

$$
\begin{aligned}
& \frac{d P}{d t}=A-\frac{S \varepsilon_{1} P m P}{N}-\frac{S \varepsilon_{2} P m l P}{N} \\
& \frac{d P m}{d t}=\frac{S \varepsilon_{1} P m P}{N}-\frac{S \varepsilon_{3} P m l P m}{N}-\frac{S \varepsilon_{4} P b P m}{N} \\
& \frac{d P m l}{d t}=\frac{S \varepsilon_{2} P m l P}{N}-\frac{S \varepsilon_{5} P m l P b}{N} \\
& \frac{d P b}{d t}=\frac{S \varepsilon_{3} P m l P m}{N}+\frac{S \varepsilon_{4} P b P m}{N}+\frac{S \varepsilon_{5} P m l P b}{N}-\mu P b
\end{aligned}
$$

Dari model diperoleh tiga titik kritis dimana $T_{1}$ dan $T_{2}$ adalah titik kritis stabil, dan $T_{3}$ adalah titik kritis tidak stabil,. Dalam model diterapkan pengendalian yang memiliki fungsi tujuan, sebagai berikut.

$$
J[S]=\int_{0}^{t f} P b(t)+P m(t)+P m l(t)+S(t)^{2} d t
$$

Dari model pengendalian diperoleh suhu optimum $11^{\circ}$. Dari pengendalian gas etilen melalui pengaturan suhu optimal $11 \mathrm{C}^{\circ}$ terlihat hasil simulasi telah berhasil memperpanjang masa simpan buah pisang.

Hasil simulasi menunjukan bahwa masa simpan populasi buah pisang dengan kondisi awal terdapat populasi buah pisang mentah, populasi buah pisang matang, dan populasi buah pisang 
busuk akan lebih lama dari pada masa simpan populasi buah pisang yang terdiri dari buah pisang mentah, buah pisang matang, dan buah pisang matang yang luka atau populasi buah pisang yang terdiri dari buah pisang mentah, buah pisang matang yang luka, dan buah pisang busuk atau populasi buah pisang yang teridiri dari buah pisang mentah, buah pisang matang, buah pisang matang yang luka, dan buah pisang busuk. Penyimpanan populasi buah pisang dengan kendali suhu optimal dapat meminimalkan banyaknya buah pisang yang busuk dan memperpanjang masa simpan buah pisang.

\section{DAFTAR PUSTAKA}

[1] Fenny. M, Bercocok Tanam Buah-buahan, Aneka Ilmu, 2002, Semarang

[2] Hayati. Nurul, Peranan Etilen Dalam Pemasakan Buah, 2012, http:// nurulhayati93 .blogspot.co .id /2012/10/Peranan Etilen - Dalam - Pemasakan-Buah, diakses 3 November 2016

[3] Luknanto. D, Model Matematika, Universitas Gajah Mada, 2003, Yogyakarta

[4] Mayer. J. Walter, Concepts of mathematical modeling, Mcgrow - hill book company, 1985. New York

[5] Naidu. D. S, Optimal control system CRC, 2002, London

[6] Paramita. Oktaviani, Pengaruh Memar Terhadap Perubahan Pola Respirasi Produksi Etilen dan Jaringan Buah Mangga (Mangifera Indica $L$ ) var Gedong Gincu pada Berbagai Suhu Penyimpanan, Universitas Negeri Semarang, 2010, Semarang

[7] Sari. Nova, Kandungan Gizi Pisang (Musa Paradisiaca L) Berdasarkan Degradasi warna kulit, Universitas Andalas, 2011, Padang

[8] Setiono, Buah Klimaterik dan Non Klimaterik, 2011, http: // setiono774 .blogspot. co. Id / 2011 / 05/buah-klimaterik-dan-non-klimaterik, diakses 3 November 2016

[9] Subiono, Sistem linear dan Kontrol Optimal, Institut Teknologi Sepuluh Nopember, 2013, Surabaya

[10] Utama. I Made Supartha, Penanganan Pascapanen Buah Dan Sayuran Segar, Fakultas Teknologi Pertanian Universitas Udayana, 2001, Bali 